\title{
South Africa's Trade Performance under Alternative Exchange Rate Regimes
}

\author{
Romaine Patrick, Phocenah Nyatanga \\ University of KwaZulu-Natal, South Africa, KwaZulu-Natal, Pietermaritzburg \\ romainepatrick@gmail.com,nyatanga@ukzn.ac.za
}

\begin{abstract}
This study examined the effect exchange rates have on import and export volumes under alternative exchange rate policies adopted in South Africa over the period 1960 to 2017. Using quarterly time series data for the stated period, a log-linear error correction model is employed to estimate the country's export and import elasticities, taking into account Gross Domestic Product (GDP), the real price of exports, the real price of imports and real exchange rates. Using the freely floating exchange rate regime as the base period, the study concluded that both export and import volumes are lower under a system of fixed exchange rates. Export and import volumes were also found to be lower under the dual exchange rate regime, relative to the freely floating exchange rate regime. In accordance with export-led growth strategies, exports were found to be higher and imports lower under a managed floating exchange rate regime. It is therefore recommended that South Africa revert to a more managed exchange rate regime, until the South African economy is developed to accommodate a freely floating exchange rate regime.
\end{abstract}

Keywords and Phrases: Error-correction model, exchange rate regime, export-supply, import-demand.

\section{Introduction}

There is a general consensus that trade occupies a crucial role in an economy's development and the exchange rate policy a country adopts has a substantial impact in determining such country's economic performance, growth and international competitiveness (Walters and De Beer, 1999; Bah and Amusa, 2003; Tarawalie, 2010). Over the last few decades, two distinct exchange rate regimes, namely fixed and floating exchange rate regimes have been presented as essential policies in determining the pace of economic development. Proponents of fixed exchange rate policies, among them Gylfason (2000), Moreno (2001), De Grauwe and Schnabl (2004) have argued that such policies provide currency and economic stability, protect small nations from external shocks, promotes international trade and investment stability and provides balance of payments stability among other advantages and to the contrary, advocates of a floating exchange rate regime, among them Friedman (1953), Bailliu et al. (2003) and Fisher (2001) have argued that the adoption of a floating exchange rate regime is desirable on the theoretical grounds of acting as an external shock absorber in times of exchange rate volatility, thereby correcting the balance of payments disequilibria and promoting economic growth. They further explain that in current times, fixing the exchange rate is unsustainable, often leading to severe recessions during times of crisis. In-between these two extremes are the dual and the managed exchange rate regimes. Whilst most developed countries departed from the fixed exchange rate in the advent of globalisation and free trade in the 1990s, many developing countries lack the financial structures to expose their economies to the volatility and uncertainty associated with a freely floating exchange rate (Moreno, 2001).

Over the past few years, the South African rand has experienced upward and downward trends, significantly affecting the country's current account (Moreno, 2001). The dramatic exchange rate fluctuations, coupled with political uncertainty, has also resulted in price instability, which has led to inflation, as well as dampened South Africa's global competitiveness and investor confidence (Fin 24,2017). Therefore, numbers of developing countries adopted a managed floating exchange rate system, thereby allowing authorities to control the value of the currency, mainly to avoid disruptions of their foreign trade and mitigate exchange rate volatility, which the economy may not be able to handle. Although the importance of exchange rate policy for economic growth and trade is a popular topic, there is still much debate amongst policymakers as to which exchange rate policy a country should adopt in a bid to confront the trade and economic development concerns of any country. Over the past decades, South Africa has adopted numerous exchange rate systems, with the objective of having a competitive exchange rate that encourages more exports and less imports, increase foreign direct investments, create more job opportunities, improve the balance of payments position and ultimately maintain stable economic growth. These exchange rate policies adopted were the fixed exchange rate (1945 to 1985), the dual exchange rate (1986 to 1995), the managed exchange rate policy 
(1996 to 2000) and the freely floating exchange rate regime (2000 to 2015) (Van der Merwe and Mollentze, 2010; Mtonga, 2011). The current policy has however left the South African Rand vulnerable to global shocks and volatility in the foreign exchange values of major currencies, especially the dollar (see Figure 1).

\section{Figure 1: South African Exchange Rate Trends (ZAR/\$) 1960 to 2015}

\section{South African Rand - US Dollar Exchange Rate 1960 to 2015}

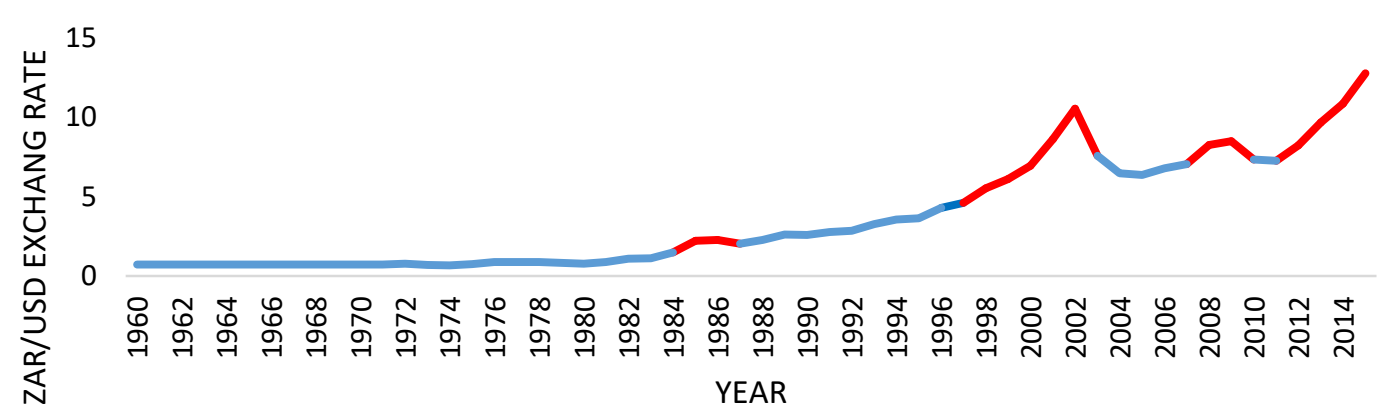

Source: South African Reserve Bank (2015)

Figure 2: South Africa's Current Account to GDP

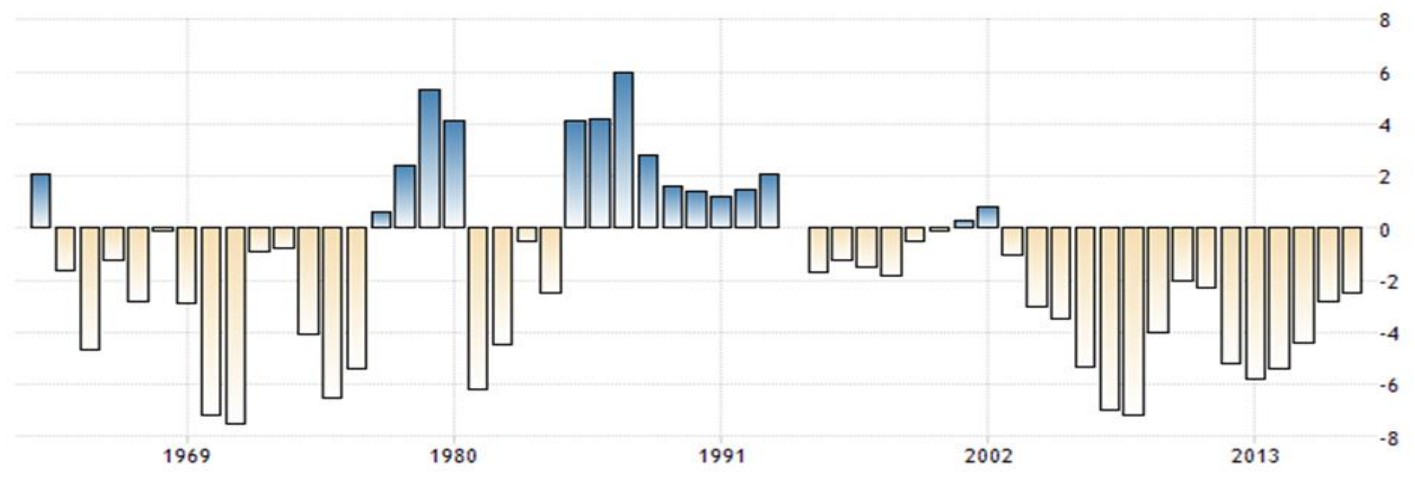

Source: tradingeconomics.com | South African Reserve bank

This has also resulted in South Africa's business confidence reaching a 32-year low, losing investment grading from two of the world's largest investment rating agencies: Standard and Poor's, and Fitch (Fin 24, 2017). Although the relationship between exchange rates, economic development and exchange rate policies remain current topics, not much research has investigated the impact alternative exchange rates policies have on South African trade. Research in South Africa has focused on the effect of real exchange rates volatility. The studies that have touched on exchange rate regimes are for outdated periods and provide inconclusive results. For example, Eun, Kilic and Lai (2012) focused on the dual exchange rate system in South Africa. Their study is limited by its study period and does not make a substantial contribution to the topic of economic or trade performance under the alternative exchange rate regimes in South Africa as only the dual exchange rate regime system is tested and discussed.

Mtonga (2011) examined whether South Africa's adoption of an inflation-targeting framework in the year 2000 was responsible for the rand's exchange rate fluctuations. The result of this study was that the change of 
monetary policy in the year 2000 did influence the pricing of the rand. However, this study did not take into account other exchange rate regimes. The change of exchange rate policy to a freely floating exchange rate regime in the year 2000 may have influenced the pricing of the rand and not only the change of monetary policy. This study therefore utilised updated time series data and advanced time series modelling techniques to inform this article. The rest of the article is organised as follows, the next section reviews the evolution of South Africa's exchange rate policies and analysis the exchange rate and trade trends over the study period (1960 to 2017), followed by a discussion of the dataset and methodology, the empirical findings and finally conclusion and recommendations.

\section{Evolution of South Africa's Exchange Rate Policies (1945 - 2017)}

South Africa's exchange rate policies have developed from fixed to managed floating and to freely floating exchange rate regimes over the years, and can be split into five periods.

The Bretton Woods System of Fixed Exchange Rates (1945 -1960): During 1945, South Africa, along with other founding members, became a signatory of the Bretton Woods monetary agreement. In the absence of an active and developed foreign exchange market, the South African pound was linked to the pound sterling (De Kock, 1954). This period was characterised by a deteriorating balance of payments and the need to promote foreign investments (Van der Merwe and Mollentze, 2010).

The disintegration of the Bretton Woods Agreement (1961 to 1985): During 1961, the rand replaced the pound as South Africa's official currency, but remained linked to the pound sterling. This period was also characterised by a significant deterioration in the balance of payments. South African authorities devalued the rand by $17.9 \%$ in September 1975 in order to improve the balance of payments position (The Department of Justice and Constitutional Development, 2002). By the late 1970s, the changing economic conditions and the deterioration of the balance of payments status led to the government appointing a commission of inquiry, known as the De Kock Commission, established in 1977 (Van der Merwe, 1996). The commission concluded that the South African exchange rate system at that time was flawed and not conducive to economic growth and achieving a stable balance of payments as well as a stable economic environment (De Kock Commission, 1979). The commission proposed that South Africa develops a unitary exchange rate system (Van der Merwe, 1996).

The goal of this system was to develop a competitive foreign exchange market in South Africa where the rand could find its own level subject to limited Reserve Bank intervention (De Kock Commission, 1979). Taking into account the commission's recommendations, steps were taken to develop the South African foreign exchange market that was free from government intervention (Van der Merwe, 1996). In the pursuit of a more flexible exchange rate system, the dual currency (the commercial and the financial) was introduced to the foreign exchange market in 1979 (De Kock Commission, 1979), where the commercial Rand rate was fixed, whilst the financial Rand rate was allowed to float freely. However, the dual currency was abolished in 1983. Following the abolishment of the dual currency, the rand remained stable until the later months of 1983, where the decline of the gold price, the debt crisis and increasing political instability led to a significant depreciation of the rand (Aron et al., 1997; Bah and Amusa, 2003). South Africa also experienced a significant decline in GDP during this period.

Dual Exchange Rate Regime (1985 to 1995): At the end of 1984, South Africa's political climate hindered the development of the foreign exchange market (see Figure 1). Due to political instability, sanctions and possibly the South African debt crisis, South Africa was forced to revert to direct control measures to manage the exchange rate and regulate the influence of capital flows on monetary reserves (Van der Merwe and Mollentze, 2010). Together with the imposition of the temporary halt on foreign loan repayments and exchange controls on capital transfers by non-residents in the form of the financial Rand, the dual exchange rate system was re-introduced and remained until the unification of the rand in 1995 (Aron et al., 1997).

Unitary Exchange Rate- Managed Floating Exchange Rate Regime (1995 to 2000): With the aim of achieving the long-term goal of complete financial liberalisation and reintegrating South Africa's economy into the global economy, the financial Rand was abolished in March 1995 and a managed exchange rate 
system, where market forces determined the spot exchange rate, was adopted. While the rand was no longer linked to the US dollar or any other currency, the Reserve Bank still participated in the market by buying and selling US dollars which had an influence on the exchange rate (Van der Merwe and Mollentze, 2010; Mtonga, 2011). The rand remained stable for a period of 11 months following the adoption of a managed floating exchange rate system. This period was characterised by a peaceful political environment together with increased foreign direct investment, warranting improved economic performance and increased economic growth rates (Mtonga, 2011).

Unitary Exchange Rate- Free Floating Rand, With Inflation Targeting Framework of Monetary Policy (2000 to current): During the year 2000, the South African Reserve Bank moved from an exchange rate targeting policy framework to an inflation rate targeting policy framework. This was followed by a gradual change to a freely floating exchange rate system, in line with achieving the fundamentals of an inflation targeting policy (Masson et al., 1997). Although South Africa has moved towards an exchange rate system where the currency is determined by market forces prior to the year 2000, Mtonga (2011) found that the move towards an inflation targeting framework in the year 2000 demarcates the previous year's attempts. The current Reserve Bank policy is to stay out of the foreign exchange market and allow the currency to be determined by market forces (SARB, 2012). Since the inflation targeting framework, South Africa enjoyed sustained economic growth rates registering growth of 5.6\% per annum in 2006 (The World Bank, 2017). However, Economic growth started decelerating in the year 2007, decreasing to 3.2\% in 2008. GDP growth further declined to $-1.5 \%$ in 2009. This negative economic growth can be attributed to the $2008 / 2009$ global financial crisis (Mnyande, 2010). The negative economic growth rate experienced in 2009 was the lowest level of economic growth recorded since independence (Mnyande, 2010). Economic growth recovered quickly in 2010, recording a growth rate of $3 \%$ per annum (The World Bank, 2017). Economic growth has remained sluggish since the year 2011, declining annually from $2.4 \%$ in 2013 to $1.2 \%$ in 2015 and $0.2 \%$ in 2016 (The World Bank, 2017). There are a few possible causes for the sluggish economic growth. One is the mining strikes and labour unrest experienced over the period 2013 to 2015, and the severe drought suffered by the agricultural sector (Hausmann, 2014). Another is the uncertain South African political climate, and dampened investor confidence (Hausmann, 2014).

\section{Data and Methodology}

The traditional import demand and export supply functions derived from Khan (1974), and expanded by Warner and Kreinin (1983), Kabir (1988), as well as Aziz (2013) are utilised in this study. This study employed time series data for the period 1960 to 2017. The period 1960 to 2017 has been chosen because the rand became the official currency from the pound in 1961. This period was also characterised by the fixed exchange rate system and a managed floating exchange rate system. The period 2000 to 2017 was characterised by a move towards a freely floating exchange rate systems. Taking into account the alternative exchange rate regimes presented in the previous section, South Africa's import demand and export supply functions are specified as follows:

$\log X V=f\left(\log G D P, \log R P X, \log R E R, \log \mathrm{MV}, D X_{1}, D X_{2}, D X_{3}, D X_{4}, Q_{1}, Q_{2}, Q_{3}, Q_{4}\right)$

$\log M V=f\left(\log G D P, \log R P M, \log R E R, \log \mathrm{XV} D X_{1}, D X_{2}, D X_{3}, D X_{4}, Q_{1}, Q_{2}, Q_{3}, Q_{4}\right)$

where XV is export volume, obtained by dividing the value of exports with its price index; MV is export volume, also obtained by dividing the value of imports with its price index; GDP is gross domestic product, and captures the effect of income on the dependent variables; RPX is the relative price of exports, obtained by dividing the export price index with the domestic price (inflation); RPM is the relative price of imports, obtained by dividing the import price index with the domestic consumer price; RER is the real exchange rate. D1, D2, D3 and D4 (base) are dummy variables that capture the effect of various exchange rate policy regimes on imports and exports, while Q1, Q2, Q3 and Q4 are quarterly dummy variables. The data used in this study is quarterly time series data, obtained from the South African Reserve Bank for the period 1960 to 2017. Since the data is quarterly in nature, quarterly dummy variables were adopted to capture the seasonal effects, with the fourth quarter as the base. Table 1 summarises the variables used in this study and the expected outcome. 


\section{Table 1: Definition of Variables}

\begin{tabular}{|c|c|c|}
\hline Variables & Definition of Variables & Expected outcome \\
\hline $\mathbf{X V}$ & $\begin{array}{l}\text { Export Volume }=\text { Value of } \\
\text { exports / export price Index }\end{array}$ & Dependent variable \\
\hline MV & $\begin{array}{l}\text { Imports Volume }=\text { Value of } \\
\text { imports } / \text { import price index }\end{array}$ & Dependent variable \\
\hline GDP & $\begin{array}{l}\text { Gross domestic product } \\
\text { (Constant US \$) }\end{array}$ & $\begin{array}{l}\text { Positive effect on the demand for imports and supply of } \\
\text { exports. See Warner and Kreinin (1983), Aydin et al. } \\
\text { (2004), Aziz (2013), Nyatanga (2017), among others. }\end{array}$ \\
\hline RPX & $\begin{array}{l}\text { Relative price of exports = } \\
\text { Export price index/ domestic } \\
\text { prices }\end{array}$ & $\begin{array}{l}\text { Positive effect on export supply (Khan, 1974; Warner and } \\
\text { Kreinin, 1983; Aziz, 2013; Nyatanga, 2017). }\end{array}$ \\
\hline RPM & $\begin{array}{l}\text { Relative price of imports = } \\
\text { Import price index/ foreign } \\
\text { prices }\end{array}$ & $\begin{array}{l}\text { Positive effect on imports (Khan, 1974; Warner and } \\
\text { Kreinin, 1983; Aziz, 2013; Nyatanga, 2017). }\end{array}$ \\
\hline RER & Real exchange rate & $\begin{array}{l}\text { Exports are expected to respond negatively and imports } \\
\text { positively to exchange rate depreciation. (Aziz, 2013; } \\
\text { Younus and Chowdury, 2006; Bahmani-Oskooee and } \\
\text { Kantipong, 2001; Nyatanga 2017), }\end{array}$ \\
\hline $\begin{array}{l}\text { DX } \\
(1960- \\
1985)\end{array}$ & $\begin{array}{l}\text { Fixed exchange rate dummy } \\
\text { variable }\end{array}$ & $\begin{array}{l}\text { Positive effect in developing countries (Morena,2001; } \\
\text { Huang and Malhotra ,2004; and Zaraga, 2014). }\end{array}$ \\
\hline $\begin{array}{l}\mathrm{DX} \\
(1985- \\
1995)\end{array}$ & $\begin{array}{l}\text { Dual exchange rate dummy } \\
\text { variable }\end{array}$ & $\begin{array}{l}\text { Positive effect in developing countries (Yeyati and } \\
\text { Strurzenegger, 2002; Calvo and Reinhart, 2002). }\end{array}$ \\
\hline $\begin{array}{l}\mathrm{DX}_{3} \\
(1995- \\
2000)\end{array}$ & $\begin{array}{l}\text { Unitary exchange rate dummy } \\
\text { variable (Managed floating } \\
\text { exchange rate) }\end{array}$ & $\begin{array}{l}\text { Positive effect in developing countries (Huang and } \\
\text { Malhotra, 2004; Adam and Cobham,2007; Rose, 2003). }\end{array}$ \\
\hline $\begin{array}{l}\mathrm{DX}_{4} \\
(2000- \\
2017)\end{array}$ & $\begin{array}{l}\text { Unitary exchange rate dummy } \\
\text { variable (Free floating rand) }\end{array}$ & $\begin{array}{l}\text { Native effect (Nilsson and Nilsson's, 2000; Zaraga, 2014; } \\
\text { and Adam and Cobham, 2007), }\end{array}$ \\
\hline Q1 & Quarter one & Seasonal effects \\
\hline Q2 & Quarter two & Seasonal effects \\
\hline Q3 & Quarter three & Seasonal effects \\
\hline Q4 & Quarter four & Seasonal effects \\
\hline
\end{tabular}

Source: Compiled by the authors

Since the data used in this study is time series by nature, it is essential to test for the stationarity properties of the variables used in order to ascertain whether the relationship between economic variables is stationary in levels or after first differencing, given that non-stationarity may yield a spurious relationship. Consequently, the Dickey-Fuller unit-root test was employed to determine the stationary properties of the data. From Table 2 , import volume, gross domestic product, the real price of exports, the real price of imports, and real exchange rates were found to be non-stationary at all levels as the null hypothesis of a unit root cannot be rejected. After first differencing, they all become stationary [I (1)]. 
Table 2: Augmented Dickey-Fuller Unit-Root and Cointegration Test Results

\begin{tabular}{|c|c|c|c|c|}
\hline Series & & Level & First Differenced & Conclusion \\
\hline \multirow[t]{2}{*}{$M V$} & $\mathrm{~T} \mu$ & 0,62 & $-15,33^{* * *}$ & $\mathrm{I}(\mathrm{I})$ \\
\hline & $\mathrm{T} \tau$ & $-1,34$ & & \\
\hline \multirow[t]{2}{*}{$X V$} & $\mathrm{~T} \mu$ & $-0,608$ & $-19,35 * * *$ & $\mathrm{I}(\mathrm{I})$ \\
\hline & $\mathrm{T} \tau$ & $-4,68 * * *$ & & \\
\hline \multirow[t]{2}{*}{$G D P$} & $\mathrm{~T} \mu$ & 11,122 & $-10,453 * * *$ & $\mathrm{I}(\mathrm{I})$ \\
\hline & $\mathrm{T} \tau$ & 4,23 & & \\
\hline \multirow[t]{2}{*}{$R P X$} & $\mathrm{~T} \mu$ & $-1,471$ & $-16,402 * * *$ & $\mathrm{I}(\mathrm{I})$ \\
\hline & $\mathrm{T} \tau$ & $-1,704$ & & \\
\hline \multirow[t]{2}{*}{$R P M$} & $\mathrm{~T} \mu$ & $-1,745$ & $-14,09 * * *$ & $\mathrm{I}(\mathrm{I})$ \\
\hline & $\mathrm{T} \tau$ & $-2,004$ & & \\
\hline \multirow[t]{3}{*}{$R E R$} & $\mathrm{~T} \mu$ & $-1,782$ & $-12.552 * * *$ & $\mathrm{I}(\mathrm{I})$ \\
\hline & $\mathrm{T} \tau$ & $-2,846 * *$ & & \\
\hline & & \multicolumn{3}{|c|}{ Engel and Granger cointergration test on residuals } \\
\hline Residuals $(X V)$ & $\mathrm{T} \mu$ & $-4,047$ & & $\mathrm{I}(0)$ \\
\hline Residuals (MV) & $\mathrm{T} \mu$ & $-4,499$ & & $\mathrm{I}(0)$ \\
\hline
\end{tabular}

Notes: (i) $T_{\mu}$ - without trend, $T_{\tau^{-}}$with trend (ii) ${ }^{* * *}$ Statistical significance at 1 percent level, ${ }^{* *}$ at 5 per cent level and ${ }^{*}$ at 10 percent level.

Table 3: Johansen's Multivariate Cointegration Test Results

\begin{tabular}{cccc}
\hline Null hypothesis & Alternative Hypothesis & \multicolumn{2}{c}{ Trace test } \\
\cline { 2 - 3 } & & Statistic & 95\% critical value \\
\hline Export function: InXV, InGDP, & $R P X, R E R$ & & \\
\hline$r=0$ & $r=0$ & 72.4649 & 54.64 \\
$r \leq 1$ & $r=1$ & $25.8305^{*}$ & 34.55 \\
$r \leq 2$ & $r=2$ & 10.3779 & 18.17 \\
$r \leq 3$ & $r=3$ & 0.0561 & 3.74 \\
\hline Import function: InMV, InGDP, & RPM, RER & \\
\hline$r=0$ & $r=0$ & 60.7949 & 54.64 \\
$r \leq 1$ & $r=1$ & $27.6525 *$ & 34.55 \\
$r \leq 2$ & 6.2351 & 18.17 \\
$r \leq 3$ & $r=2$ & 0.4995 & 3.74 \\
\hline
\end{tabular}

Note: *reject null hypothesis at 5\% level of significance, $r$ implies the number of Cointegrating Vectors

The study further applies the Engel-Granger (1987) two-step procedure for cointegration. It was concluded that the error term for both export and import functions had no unit root, I (0). The Johansen (1988) cointegration technique, which is based on maximum likelihood estimation to determine cointegration, was also applied. From Table 3, both the functions' "trace statistic" rejected the null hypothesis of no cointegration vectors $(r=0)$, but the null hypothesis of one Cointegrating vector $(r \leq 1)$ could not be rejected at 5 percent level of significance. Based on these test results, this study adopts the error correction model. The error correction model has also been used in similar studies study such as Kumar (2012), Aziz (2013), Nyatanga 
(2017) amongst others. The export supply log-linear error correction model is expressed in equation 3 and the import demand log-linear error correction model is expressed in equation 4:

$$
\begin{aligned}
& \Delta \log X V_{t}=\alpha^{S}+\beta_{1}^{S} \Delta \log G D P_{t}+\beta_{2}^{S} \Delta \log R P X_{t}+\beta_{3}^{S} \Delta \log R E R_{t}+\beta_{4}^{S} \Delta \log M V_{t}+\sum_{j=1}^{5} \delta_{j}^{S} \Delta D_{j, t}+\sum_{j=1}^{4} \vartheta_{j}^{S} \Delta Q_{j, t}+ \\
& \gamma\left[\alpha_{0}^{L}+\alpha_{1}^{L}(t-1)+\beta_{1}^{L} \Delta \log G D P_{t-1}+\beta_{2}^{L} \Delta \log R P X_{t-1}+\beta_{3}^{L} \Delta \log R E R_{t-1}+\beta_{4}^{L} \Delta \log M V_{t-1}+\sum_{j=1}^{5} \delta_{j}^{L} \Delta D_{j, t-1}+\right. \\
& \left.\sum_{j=1}^{4} \vartheta_{j}^{L} \Delta Q_{j, t}-\log X V_{t-1}\right]+\varepsilon_{t}^{S}
\end{aligned}
$$

$$
\begin{array}{r}
\Delta \log M V_{t}=\vartheta^{S}+\varphi \Delta \log G D P_{t}+\varphi_{2}^{S} \Delta \log R P M_{t}+\varphi_{3}^{S} \Delta \log R E R_{t}+\varphi_{4}^{S} \Delta \log X V_{t}+\sum_{j=1}^{4} \theta_{j}^{S} \Delta Q_{j, t}+\tau\left[\vartheta_{0}^{L}+\right. \\
\vartheta_{1}^{L}(t-1)+\varphi_{1}^{L} \Delta \log G D P_{t-1}+\varphi_{2}^{L} \Delta \log R P X_{t-1}+\Delta \log R E R_{t-1}+\varphi_{4}^{L} \Delta \log X V_{t-1}+\sum_{j=1}^{5} \rho_{j}^{L} \Delta D_{j, t-1}+ \\
\left.\sum_{j=1}^{4} \theta_{j}^{L} \Delta Q_{j, t}-\log X V_{t-1}\right]+\omega_{t}^{S}
\end{array}
$$

Where $\alpha, \beta_{1}, \beta_{2}, \beta_{3}, \delta$ and $\gamma$ as well as $\vartheta, \varphi_{1}, \varphi_{2}, \varphi_{3}, \rho$ and $\tau$ are the unknown regression parameters to be estimated in the export (equation 3), and import (equation 4) functions respectively. Superscript $S$ represents the short-term and $L$ the long-term. The export supply adjustment coefficient is expressed as $\gamma,(0<\gamma<1)$, whilst the import demand adjustment coefficient is expressed as $\tau,(0<\tau<1)$. Following Engel and Granger (1987), the two-step procedure is applied. The first step estimates the long-run parameters for the export supply and import demand function as follows:

$$
\begin{aligned}
& \log X V_{t-1}=\alpha_{0}^{L}+\alpha_{1}^{L}(t-1)+\beta_{1}^{L} \Delta \log G D P_{t-1}+\beta_{2}^{L} \Delta \log R P X_{t-1}+\beta_{3}^{L} \Delta \log R E R_{t-1}+\quad \beta_{4}^{L} \Delta \log M V_{t-1}+ \\
& \sum_{j=1}^{5} \delta_{j}^{L} \Delta D_{j, t-1}+\sum_{j=1}^{4} \vartheta_{j}^{L} \Delta Q_{j, t}-\log X V_{t-1}+\varepsilon_{t-1}^{L} \\
& \log M V_{t-1}=\vartheta_{0}^{L}+\vartheta_{1}^{L}(t-1)+\varphi_{1}^{L} \Delta \log G D P_{t-1}+\varphi_{2}^{L} \Delta \log R P M_{t-1}+\varphi_{3}^{L} \Delta \log R E R_{t-1}+\quad \varphi_{4}^{L} \Delta \log X V_{t-1}+ \\
& \sum_{j=1}^{5} \rho_{j}^{L} \Delta D_{j, t-1}+\sum_{j=1}^{4} \theta_{j}^{L} \Delta Q_{j, t}-\log M V_{t-1}+\omega_{t-1}^{L} \quad \text {.. }
\end{aligned}
$$

The second step estimates the short-run parameters by substituting equations 3 and 4 into equations 5 and 6 respectively, as per the equations below:

$$
\begin{array}{r}
\Delta \log X V_{t}=\alpha^{S}+\beta_{1}^{S} \Delta \log G D P_{t}+\beta_{2}^{S} \Delta \log R P X_{t}+\beta_{3}^{S} \Delta \log R E R_{t}+\beta_{4}^{S} \Delta \log M V_{t}+\sum_{j=1}^{5} \delta_{j}^{S} \Delta D_{j, t}+\sum_{j=1}^{4} \vartheta_{j}^{S} \Delta Q_{j, t}- \\
\gamma \varepsilon_{t-1}^{L}+\varepsilon_{t}^{S} \\
. .(7)
\end{array}
$$

Equation 9 and 10 respectively express the long-run and short-run expenditure elasticities.

$$
\begin{aligned}
\frac{\partial \log X V_{t}}{\partial \log G D P} & =\frac{\Delta X V / X V}{\Delta G D P / G D P}=\beta 1^{\text {term }} \\
\frac{\partial \log X V_{t}}{\partial D_{j t}^{\text {term }}} & =\delta_{j t}^{\text {term } X V_{t}} \\
\text { term } & =L, S
\end{aligned}
$$

All effects and elasticities are calculated at the sample mean and vary with variables $M V_{t,} G D P_{t}, R P X_{t}, R P M_{t}$ and RERt.

\section{Results and Discussion}

Based on the elasticity results presented in Table 4, GDP has a positive and statistically significant effect on export volumes, in the long- and short-term, while the effect on imports is only significant in the long-term. Ceteris paribus, a $1 \%$ increase in domestic income results in $0.83 \%$ increase in exports in the short-term and $0.33 \%$ in the long-term. Ceteris paribus, given a $1 \%$ increase in GDP, imports increase by $0.049 \%$ in the short run and $0.132 \%$ in the long-term. This result is consistent with previous studies by Warner and Kreinin (1983), Aydin et al. (2004), Aziz (2013), Nyatanga (2017), amongst others, who found that an increase in a country's real income level leads to increased export and import volumes. 
Table 4: Estimates Elasticities

\begin{tabular}{|c|c|c|c|c|}
\hline \multirow[t]{2}{*}{ Variable } & \multicolumn{2}{|c|}{ Export Elasticities } & \multicolumn{2}{|c|}{ Import Elasticities } \\
\hline & Short-term & Long-term & Short-term & Long-term \\
\hline \multirow{2}{*}{ InGDP } & $\mathrm{x}$ & $0.329 * * *$ & 0.049 & $0.132 * * *$ \\
\hline & {$[4.15]$} & {$[21.77]$} & {$[0.24]$} & {$[3.50]$} \\
\hline \multirow[t]{2}{*}{ InRER } & $0.166 * *$ & 0.099 & $0.279 * * *$ & $-0.316^{* * * *}$ \\
\hline & {$[2.25]$} & {$[1.81]$} & {$[3.17]$} & {$[-4.07]$} \\
\hline \multirow[t]{2}{*}{ InRPX } & $-0.278 * *$ & -0.009 & - & - \\
\hline & {$[-1.95]$} & {$[-0.13]$} & - & - \\
\hline \multirow[t]{2}{*}{$\operatorname{InRPM}$} & - & - & $-0.423 * * *$ & $-0.662 * * *$ \\
\hline & - & - & {$[-2.90]$} & {$[-6.01]$} \\
\hline \multirow{2}{*}{$\operatorname{In} X V$} & - & - & 0.06 & $0.627 * * *$ \\
\hline & - & - & [0.94] & {$[6.30]$} \\
\hline \multirow[t]{2}{*}{$\operatorname{In} M V$} & 0.047 & $0.181 * * *$ & - & - \\
\hline & {$[0.76]$} & {$[4.09]$} & - & - \\
\hline \multirow[t]{2}{*}{$D X 1960-1985$} & -0.003 & $0.473 * * *$ & -0.008 & -0.136 \\
\hline & {$[-0.41]$} & {$[9.17]$} & {$[-0.75]$} & {$[-1.44]$} \\
\hline \multirow[t]{2}{*}{ DX 1986-1995 } & -0.014 & $0.197 * * *$ & -0.003 & $-0.486 * * *$ \\
\hline & {$[-1.47]$} & {$[4.75]$} & {$[-0.23]$} & {$[-9.57]$} \\
\hline \multirow[t]{2}{*}{$D X 1996-2000$} & 0.004 & $0.124 * * *$ & -0.004 & $-0.362 * * *$ \\
\hline & {$[0.32]$} & {$[3.21]$} & {$[-0.25]$} & {$[-8.43]$} \\
\hline \multirow[t]{2}{*}{ Quarter 1} & 0.03 & 0.004 & -0.005 & -0.027 \\
\hline & {$[1.46]$} & {$[0.22]$} & [0.36] & {$[-0.98]$} \\
\hline \multirow[t]{2}{*}{ Quarter 2} & -0.003 & -0.004 & $0.066 * * *$ & -0.002 \\
\hline & {$[-0.26]$} & {$[-0.22]$} & {$[4.85]$} & {$[-0.08]$} \\
\hline \multirow{2}{*}{ Quarter 3} & 0.031 & 0.011 & $0.065 * * *$ & 0.02 \\
\hline & {$[1.64]$} & {$[0.55]$} & [4.97] & {$[0.73]$} \\
\hline \multirow[t]{2}{*}{ Constant } & $-0.027 * *$ & $1.625 * * *$ & $-0.0001 * * *$ & $2.024 * * *$ \\
\hline & {$[-2.14]$} & {$[5.62]$} & {$[-2.93]$} & {$[4.15]$} \\
\hline Adjustment Coefficient & -0.012 & & -0.0001 & \\
\hline Adjusted $R$-sqr & 0.1617 & 0.9736 & 0.2950 & 0.9411 \\
\hline
\end{tabular}

Note: i. ${ }^{* *}$ when p-value $\leq 0.05$, and ${ }^{* * *}$ when $\mathrm{p}$-value $\leq 0.01$. ii. Numbers in parentheses are t-ratios

The short-term and long-term regression results reveal that the real price of exports has a negative, though inelastic effect in determining export volumes, and only statistically significant in the short-term. The shortterm and long-term results are inconsistent with the findings from previous studies of Khan (1974) and Warner and Kreinin (1983), who found that exports respond positively to export price increases. The price of exports is an indicator of South Africa's competitiveness. The higher the price of South African exports, the less competitive South Africa is as compared to the rest of the world, and the less South African produced goods and services are demanded by the rest of the world. Since South Africa is a relatively small economy as compared to the rest of the world and a net importer of goods, South Africa is regarded as a price taker in international markets. Therefore, South African exports are elastic to the rest of the world.

When the price of exports increases, other countries can do without South African products. On the one hand, the responsiveness of imports to a change in the real price of imports is highly significant in the long-term and short-term. The relationship between import volume and the price of imports is negative, which was expected and consistent with economic theory. As per the regression results displayed in Table 5 above, Ceteris paribus, given a $1 \%$ increase in real import prices, imports decrease by $0.423 \%$ in the short-term and $0.662 \%$ in the long-term. The relationship between export volumes and real exchange rates is relatively inelastic and statistically significant. Ceteris paribus, the regression results mean, given a $1 \%$ increase in real exchange rates, exports increase by $0.166 \%$ in the short-term and by $0.099 \%$ in the long-term. Interestingly, the rand depreciation has a positive effect on import demand in the short-term. Ceteris paribus, given a $1 \%$ increase in the real exchange rate, imports increase by $0.279 \%$ in the short-term and decreases imports by $0.316 \%$ in the long-term. As expected and consistent with economic theory, the depreciation of the rand increases exports and decreases imports in the long-term. Export volume has a positive effect on import demand, and import volume has a positive effect on export supply. 
According to the regression results, ceteris paribus, a 1\% increase in export volume, increases imports by $0.06 \%$ in the short-term and by $0.627 \%$ in the long-term. Ceteris paribus, a $1 \%$ increase in import volumes, results in export volumes increasing by $0.047 \%$ in the short-term and by $0.181 \%$ in the long-term. These results are consistent with the fact that South Africa is a net importer of machinery and raw materials used in the production of exports. Therefore, increased demand for South Africa goods abroad, results in an increase in the demand for machinery and raw materials imported from foreign countries. As far as policies are concerned, the fixed exchange rate system adopted in 1960 to 1985 had a statistically significant effect on export supply relative to the base period of a floating exchange rate regime in the long-term. However, there was no significant difference in export volumes under the two exchange rate regimes in the short-term. In the long-term, export volumes were $0.473 \%$ higher 'between' 1960 to 1985 compared to the base period of floating exchange rate (2000-2015). Consistent with findings from studies by Levy-Yeyati and Strurzenegger (2002), Edwards and Yeyati (2003) and Calvo and Reinhart (2002), fixed exchange rates have a positive effect on the economy in the short-term.

Although exports are higher under this regime as compared to the base period of floating exchange rates, Calvo and Reinhart (2002) warn that in the long-term a fixed exchange rate is not conducive to economic growth and may lead to a financial crisis, as experienced in other developing countries such as Thailand and Brazil. For import volumes, while negative, no statistically significant difference was found under the two exchange rate regimes. It is necessary to note that, during the 1960 to 1985 period, the South African government intervened to reduce imports and increase exports by introducing import tariffs, import surcharges and import licenses. Authorities also devalued the currency to improve South Africa's balance of payments. This together with the oil crisis in 1973 could be acceptable explanations for the decreased import volumes during this period of fixed exchange rates as compared to the base period. Export volumes were significantly higher under the dual exchange rate system, than the base period of freely floating exchange rates in the long-term. In the short-term, no significant difference was observed. According to the regression results (Table 5), exports were $0.014 \%$ less in the short-term and $0.197 \%$ higher in the long-term. Consistent with the J-curve phenomenon, the rand depreciation during this period did not have a positive effect on exports in the short-term but improved in the long-term. Imports under the dual exchange rate system were not significantly different in the short-term but significantly different in the long-term.

Ceteris paribus, import volumes are $0.003 \%$ less under the dual exchange rate system than the freely floating exchange rate system, whilst import volumes are $0.486 \%$ less in the long-term compared to the era of freely floating exchange rates. Economic sanctions enforced on South Africa in 1985 have contributed to the lower import volumes under the dual exchange rate system when compared to the freely floating exchange rate system. Political instability has also hindered economic growth and international trade during this period. The responsiveness of exports under the managed floating exchange rate regime was positive but insignificantly different in the short-term and statistically significant in the long-term at $1 \%$ level. South Africa's export volume was $0.004 \%$ more in the short-term and $0.124 \%$ more in the long term. The removal of sanctions, economic liberalisation, and reintegration of South Africa into the global economy could have also contributed towards the positive response of exports under the managed floating exchange rate regime than the freely floating exchange rate system. This result is consistent with the improvement of the balance of trade surplus at the beginning of 1996. According to Edwards (2005), export volumes increased as a percentage of GDP from $20 \%$ in 1990 to $29 \%$ in 2000 .

Import demand under the managed floating exchange rate system was significantly different in the long-term and not significantly different in the short-term. Imports were $0.004 \%$ lower in the short-term and $0.362 \%$ lower in the long-term as compared to the base period of freely floating exchange rates. Although economic sanctions were removed during this period, imports were negative during this period. The managed floating system coupled with the peaceful transition to a democratic country could have brought about improved economic growth and decreased imports, thereby improving South Africa's balance of payments position. The results are consistent with the improvement of the balance of trade surplus at the beginning of 1996. The adjustment coefficient for export and import volumes is $0.012 \%$ and $0.0001 \%$ respectively, following a disequilibrium in the export and import function with only a minuscule small proportion corrected within a quarter. Export supply and import demand adjustments are slow in the long-term. 


\section{Conclusion}

In view of the above findings, it can be concluded that in the long run, exchange rate regimes do matter for trade. When comparing the freely floating exchange rate regime (year 2000 to current), to the fixed exchange rate regime, the dual exchange rate regime and the managed floating exchange rate regime, it was found that South African trade performed better under a fixed or managed exchange rate regime than the freely floating exchange rate regime. This study's findings are consistent with economic theory and empirical studies that developing countries perform better under a more managed or fixed exchange rate regime. However, caution should be taken when considering the adoption of a fixed exchange rate regime as it can be costly to maintain and may not be sustainable in the long run. It is therefore recommended that South Africa adopts a managed floating exchange rate regime until its markets and the economy are developed to deal with exchange rate fluctuations associated with a freely floating exchange rate regime. The objective of the South African Reserve Bank is to maintain price stability through the inflation rate-targeting framework. However, the adoption of a freely floating exchange rate implies that import and export prices also fluctuate, defeating the objective of monetary policy. A study by Gupta (2012) revealed that South Africa's inflation rate was more volatile since the year 2000, when the South African Reserve Bank discarded exchange rate targeting and adopted an inflation rate-targeting framework. As a result, it is recommended that the Reserve Bank should consider reverting to an exchange rate targeting framework.

\section{References}

Adam, C. \& Cobham, D. (2007). Exchange rate regimes and trade. Manchester School University of Manchester, 75 (1), 44-63.

Aron, J., Elbadawi, I. \& Kahn, B. (1997). Determinants of the real exchange rate in South Africa. Centre for the Study of African Economies working paper series no. 97-16. Institute of economics and statistics: Oxford University.

Aydin, M. F., Ciplak, U. \& Yucel, E. M. (2004). Export Supply and Import Demand Models for the Turkish Economy. Research Development Working Paper, 04/09. The Central Bank of the Republic of Turkey.

Aziz, M. N. (2013). Modelling of import demand function for a developing country: An empirical approach, Asian- African Journal of Economics and Econometrics, 13(1), 1-15.

Bah, I. \& Amusa, H. A. (2003). Real exchange rate volatility and foreign trade: evidence from South Africa's exports to the United States, The African Finance Journal, 5(2), 1-20.

Bahmani-Oskooee, M. \& Kantipong, T. (2001). Bilateral j-curve between Thailand and her trading partners, Journal of Economic Development, 26(2), 107-116.

Bailliu, J., Lafrance, R. \& Perrault, J. F. (2003). Does exchange rate policy matter for growth, International Finance, 6(3), 381-414.

Calvo, G. A. \& Reinhart, C. M. (2002). Fear of Floating, Quarterly Journal of Economics, 117(2), 379-408.

De Kock, commission. (1979). Commission of inquiry into the monetary system and monetary policy in South Africa: exchange rates in South Africa (interim report). Pretoria, Government Printer.

De Kock, G. P. C. (1954). History of the South African Reserve Bank: 1920 - 1952. Pretoria, Van Schaik Publishers.

De Grauwe, P. \& Schnabl, G. (2004). Exchange rates regimes and macroeconomic stability in central and Eastern Europe. CESifo Working Paper, 1182, 1-34.

Edwards, L. (2005). Has South Africa liberalised its trade? South African Journal of Economics, 73(4), 754-775.

Edwards, S. \& Levy-Yeyati, E. (2003). Flexible exchange rates as shock absorbers. NBER Working paper series, 9867, 1-30.

Eun, C., Kihc, R. \& Lai, S. (2012). A tale of two exchange rates: South Africa's Dual- Rate experiment. Atlanta, Federal Reserve Bank of Atlanta.

Fin, 24. (2017). SA business confidence hits 32-year low. Fin24 [Internet], 06 September. Available from: www.fin24.co.za [Accessed 18 February 2018].

Fisher, S. (2001). Exchange rate regimes: is the bipolar view correct? Journal of Economic Perspectives, 15(2), 3-24.

Friedman, M. (1953). The case of flexible exchange rates. In: De Grauwe, P. \& Schnabl, G. (2004). Exchange rates regimes and macroeconomic stability in central and Eastern Europe. CESifo Working Paper, 1182, 1-34. 
Gupta, R. (2012). Should the South African reserve bank respond to exchange rate fluctuations? evidence from the cosine-squared cepstrum. University of Pretoria, Department of Economics Working Papers.

Gylfason, T. (2000). Fix or Flex? Alternative Exchange Rate Regimes in an Era of Global Capital Mobility", North American Journal of Economics and Finance, 11(2), 173-189.

Huang, H. \& Malhotra, P. (2004). Exchange rate regimes and economic growth: evidence from developing Asian and advanced European Economies. IMF Working paper series, 1-32.

Hausmann, R. (2014). Understanding SA's poor economic performance.

Kabir, R. (1988). Estimating import and export demand functions, the case of Bangladesh. The Bangladesh Development Studies, 16(4), 40-55.

Khan, M. S. (1974). Import and export demand in developing countries. IMF Staff, 21, 678-693.

Kumar, A. T. (2012). An error-correction analysis of India-US trade flows, Journal of Economic Development, $37(1), 29-51$.

Levy-Yeyati, E. \& Sturzenegger, F. (2002). To float or to fix: evidence on the impact of exchange rate regimes on growth, American Economic Review, 12(2), 1-49.

Masson, P., Savastano, M. \& Sharma, S. (1997). The scope for Inflation targeting in developing countries. International Monetary Fund Working Paper No. 97/130.

Moreno, R. (2001). Pegging and stabilization policy in developing countries, Economic Review of the Federal Reserve Bank of San Francisco, 12(99), 17-29.

Mtonga, E. (2011). Did it matter monetary policy regime change and exchange rate dynamics in South Africa. Lusaka, Working Paper.

Mnyande, M. (2010). The role of monetary policy in influencing savings behaviour in the South African economy. South Africa: South African Reserve Bank.

Nilsson, K. \& Nilsson, L. (2000). Exchange rate regimes and export performance of developing countries, The World Economy, 23(3), 331- 349.

Nyatanga, P. (2017). An error correction analysis of Zimbabwe's trade performance and development under alternative trade policy regimes, Foreign Trade Review, 52(2), 90-105.

Rose, A. (2003). Which international institutions promote international trade? CEPR Discussion paper no 3764.

SARB (South African Reserve Bank). (2012). Exchange rate policy. SARB [Internet], March. Available from:<http://www2.resbank.co.za/internet/Glossary.nsf/0/6e77f482c063ea5742256b430031f732 ?OpenDocument> [accessed on 17 June 2017]

South African Reserve Bank. (2015). South African Reserve Bank (SARB) [Internet]. Available from:<https://www.resbank.co.za/Research/Statistics/Pages/OnlineDownloadFacility.aspx> [Accessed 7 August 2017].

Tarawalie, B. (2010). Real exchange rate behaviour and economic growth: Evidence from Sierra Leone, South African Journal of economic management, 13(1), 8-25.

The Department of Justice and Constitutional Development (the DOJ \& CD). (2002). Final report of the commission of inquiry into the rapid depreciation of the rand and related matters.

The World Bank. (2017). World Bank Open Data [Internet]. Available from: < http://data.worldbank.org/> [Accessed 07 August 2017].

Trading Economics. (2015). South African Rand, Actual and Historical data. Trading Economics, [Internet]. Available from: <http://www.tradingeconomics.com/south-africa/currency>. [Accessed 5 March 2015].

Van der Merwe, E. \& Mollentze, S. (2010). Monetary economics in South Africa. Cape Town: Oxford University Press.

Van der Merwe, E. J. (1996). Exchange rate management policies in South Africa: recent experience and prospects. Occasional paper no, 9. South African Reserve Bank.

Walters, S. \& De Beer, B. (1999). An indicator of South Africa's external competitiveness. South African Quarterly Bulletin no, 213. Washington, Institute for International Economics.

Warner, D. \& Kreinin, M. E. (1983). Determinants of international trade flows. The Review of Economics and Statistics, 65(1), 96-104.

Younus, S. \& Chowdhury, M. I. (2006). An analysis of Bangladesh's transition to flexible exchange rate regime. The Bangladesh Bank, Working paper series no, WP 0706. Policy Analysis Unit (PAU).

Zaraga, L. (2014). Effects of exchange rate regimes on trade: the case of silver standard India. North-Western University. 